\title{
DROSERA REGIA STEPHENS
}

Nigel HewitT-Cooper • T he Homestead • G lastonbury Road • West Pennard • Somerset, BA 6 8N N

•UK・sales@hccarnivorousplants.co.uk

Keywords: Cultivation: Drosera regia

M uch has been written about this interesting species of sundew over the years, both in the popular literature and indeed on-line in more recent times. M uch of what is written would serve to discourage the average hobbyist from attempting cultivation, and as a result until surprisingly recently D rosera regia was scarcely seen. The truth however, is that this plant is generally easy to grow successfully, and once established is a long lived perennial which can attain huge dimensions.

Although it is becoming commoner in peoples collections, it remains exceedingly rare in the wild, with one of the smallest and most endangered natural ranges of any D rosera species. It is found in a single remote valley at Bainskloof, near Cape Town in South Africa at an altitude of 600-900 m, where it exists as two separate colonies, one of which could possibly al ready be extinct (pers. comm.) It has been suggested that the two colonies differ by one having slightly broader leaves. Here they are found growing amongst dense grasses which make them somewhat difficult to find, and indeed they compete with the surrounding vegetation by producing their sword-shaped lanceolate leaves up to $50 \mathrm{~cm}$ in length-the largest of any D rosera. At their bases the leaves can be up to $2 \mathrm{~cm}$ wide, gradually tapering to a point at their apex, with many large tentacles up to $4 \mathrm{~mm}$ in length, each topped with a generous droplet of mucilage found on the upper surface of the leaf, facing inwards toward the growth point (see Fig. 1). The rear of the leaves is glabrous, with a large raised central vein which runs the entire length. They are a uniform bright apple green color, with the central vein being slightly lighter, and suffusing red at their base by the growth point (see Fig. 2).

Producing leaves of this size enables the plant to capture insect prey of a substantially larger bulk than other species, and unlike other upright species such as D rosera filiformis from $\mathrm{N}$ orth A merica, and D rosera graminifolia from South A merica, Drosera regia has not only active tentacles, but is able to curl its leaves along their entire length. This power of movement ensures that the plant can catch and hold prey as large as the common wasp Vespula vulgaris, the leaves often folding over more than $360^{\circ}$ in the struggle.

The large amount of mucilage produced by the tentacles mean that this species catches many more insects than others, and its leaves can become black with insect carcases.

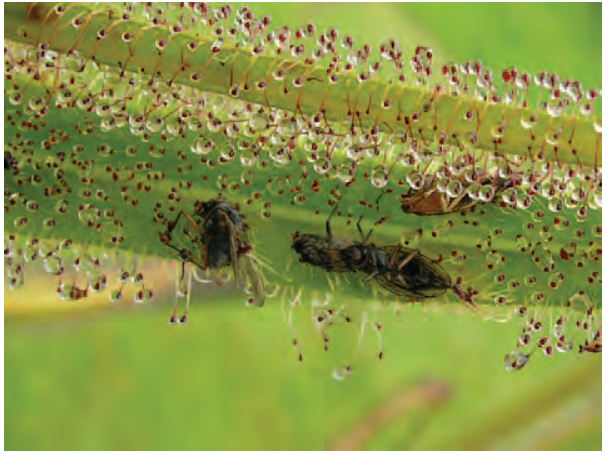

Figure 1: Close up of Drosera regia leaves.

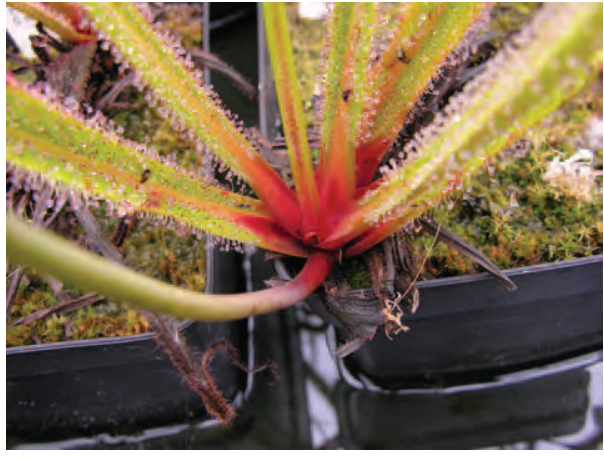

Figure 2: Red leaf bases of Drosera regia. 


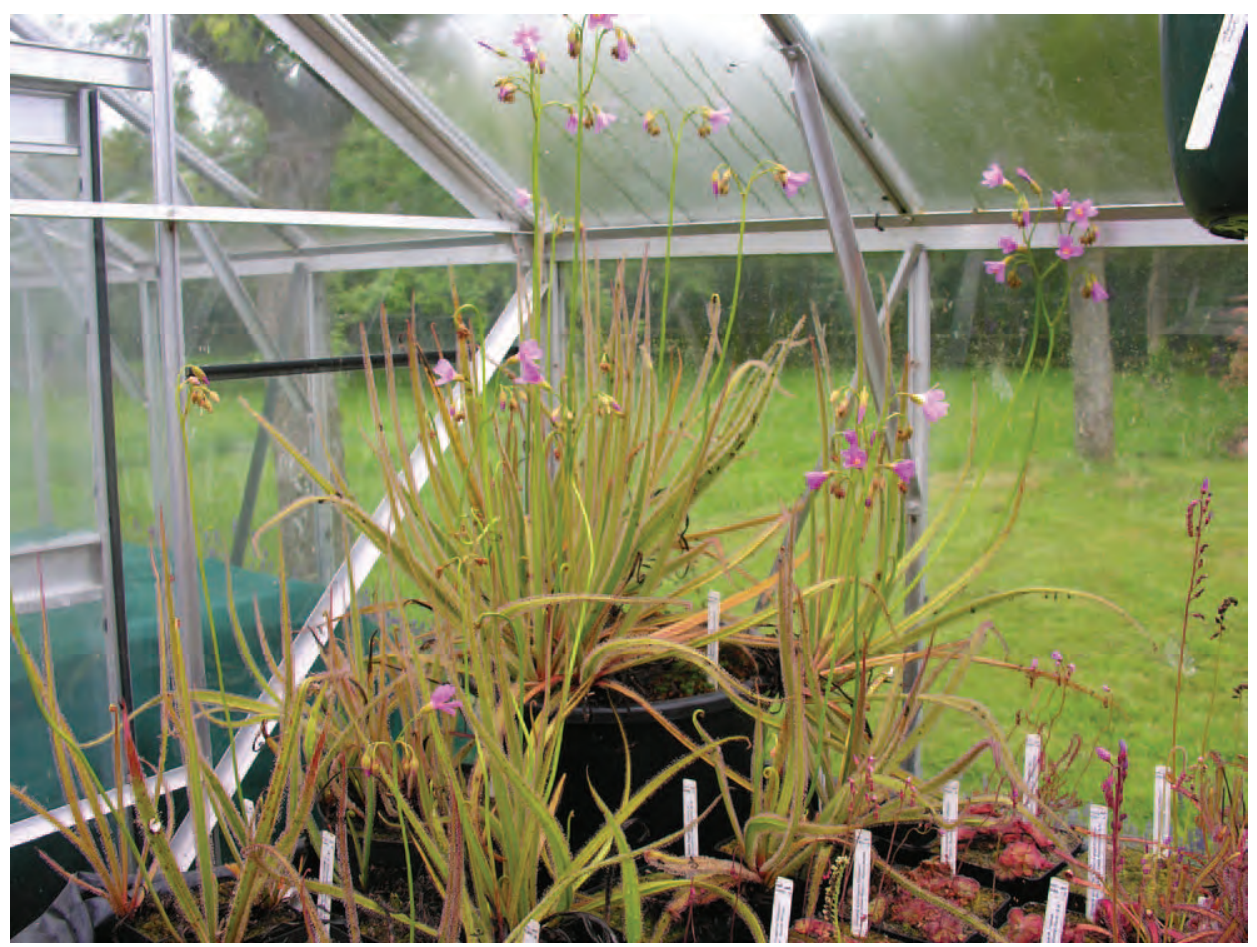

Figure 3: Adult Drosera regia plants.

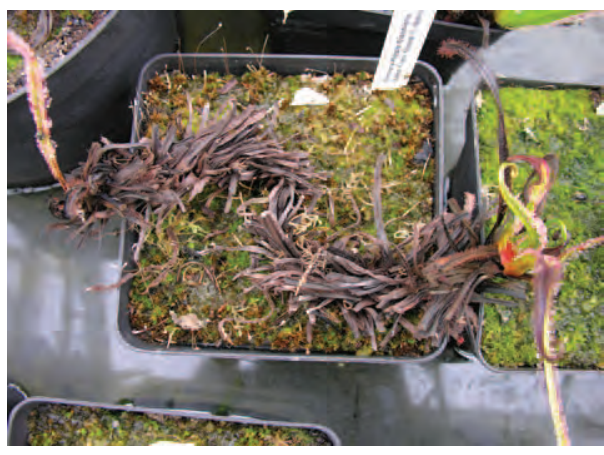

Figure 4: Drosera regia plants emerging from dormancy.
This plant has the unusual characteristic of producing a rhizome, which is clothed by dead leaf bases and which, periodically, divides into two branches. Over many years the whole plant can become very large with numerous growth points. My original plant, which is now over 18 years old, has 6 such growth points and over-hangs its 35 -liter pot. It is approximately $60 \mathrm{~cm}$ across with leaves usually in excess of $45 \mathrm{~cm}$ in length, produced each year (see Fig. 3).

Their growth pattern is fairly similar to many other South African Drosera species. Over winter when the light levels drop, they lose their growth, producing a kind of loose hibernacula of tiny truncated leaves sometimes barely $1 \mathrm{~cm}$ in length (see Fig. 4). A t this time they are fairly tol erant of low temperatures, enduring the occasional freeze. With the increase in day length, growth resumes in early $M$ arch, and within one month they can produce a rosette of 4 or 5 mature leaves which unfurl watch-springlike until they are fully open.

The first flush of leaves are followed by flower stalks which are easily recognisable as they are circular in cross section, glabrous, and with a narrowly ovate embryonic bud covered in short, 




Figure 5: Glandular Drosera regia calyx lobes.

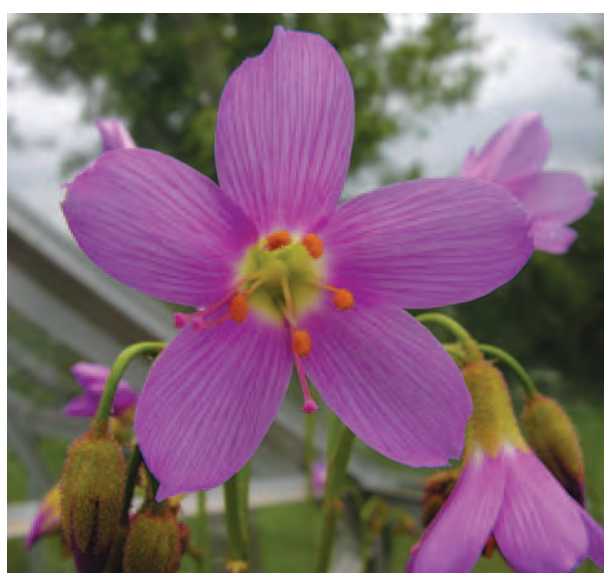

Figure 6: The stigmas are simple and unreceptive.

stalked red glandular hairs-protection from sap sucking insects (see Fig. 5). The flower scapes are usually taller than the leaves and can branch several times, so a single stem may support as many as 20 flowers. The flowers themselves are spectacular, up to $3 \mathrm{~cm}$ in diameter, bright pink with darker pink veins running the length of each petal, with the green glandular calyx lobes holding their bases together so that a tube is formed, from which emerge the anthers and

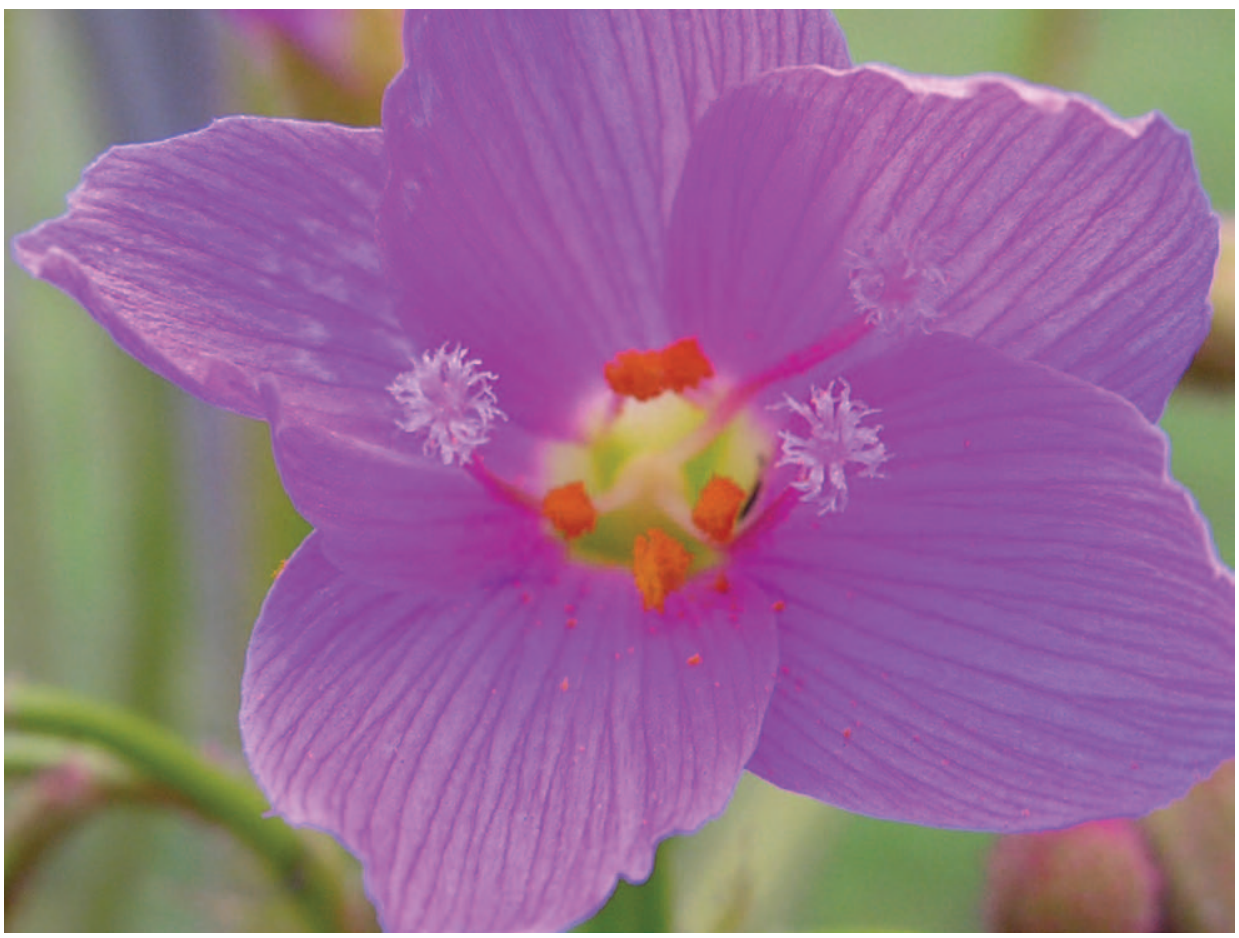

Figure 7: Receptive, fimbriate stigmas, clearly visible. 
stigmas. This species is usually regarded as being self sterile, but the flowers have a mechanism for reducing the risk of self pollination. B right yellow pollen is released copiously shortly after opening, but at this time the stigmas are simple, unbranched, and un-receptive (see Fig. 6). Once the pollen has been released, the stigma tips open and feather out, becoming fimbriate (see Fig. 7). When this occurs, the flower can be pollinated with pollen from another flower (although some residual pollen may be released from the same flower). Several flowers open together to give a better chance of seed-set, and I have obtained a good quantity of seed from single clones. The seeds are falcate and $2 \mathrm{~mm}$ in length (see Fig. 8). Of course, having more than one clone is preferable as the resulting progeny are likely to be more variable and vigorous.

After flowering, growth continues, with each growth point producing several more leaves, which toward the end of the season become progressively shorter as autumn approaches. With the onset of winter, the glandular leaves die back and dormancy begins.

Despite what has written about this plant, it is easy to grow in cultivation and as I've already stated is long-lived. $M$ ine grow in the same bed as my other summer growing South A frican species such as D. capensis, D. admirabilis, and D. slackii, with a southerly aspect in full sun, and stood in 2-3 inches of rain water for the growing season. Over winter the water is reduced down so as the compost remains damp, but doesn't dry out. I use a silver sand and peat moss mix to a ratio of $60 \%$ sand and $40 \%$ peat which gives good results.

Seed is the best method of producing a number of plants, but it is somewhat slower than in other species. Seed appears not to require any pre-treatment and can be surface sown on plain peat moss in the spring and early summer. Keep in a sunny position and in a tray of rain water, and germination commences in 3-5 weeks. I find it best to leave the seedlings until they are at least $2 \mathrm{~cm}$ in height before potting separately in to $7-8 \mathrm{~cm}$ pots in the same compost as mentioned above.

Root cuttings work well, and can easily be taken without disturbing the adult plant (which

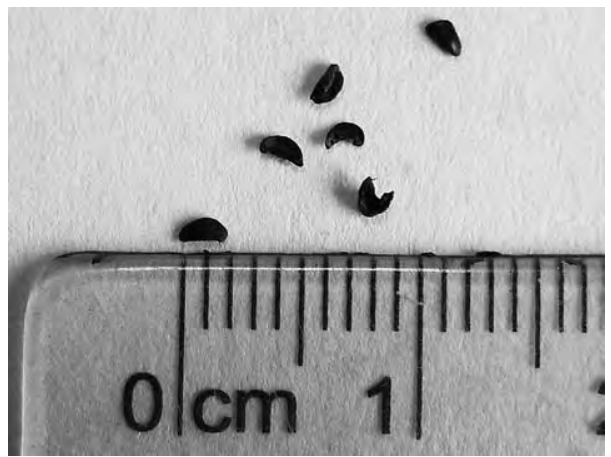

Figure 8: Close-up of fresh Drosera regia seed. they seem to dislike, by the way), as they frequently grow out of the drainage holes of their containers and can simply be cut off. Reduce each root to $5 \mathrm{~cm}$ in length, and lay on the surface of peat moss. Cover lightly with some torn sphagnum moss, water well from above with rain water, and enclose in a plastic bag to maintain a high humidity. Keep in a bright position away from direct sunlight to avoid overheating, and check weekly. In approximately 4 weeks, the roots will produce tiny green buds which will develop into new plants. Once they are growing well, gradually harden off the plants by making a small hole in the bag, increasing the size of it a little each day for a week, at which time the bag can be removed. A s with the seedlings, leave the young plants until they are $2 \mathrm{~cm}$ in height before potting separately. The cuttings are best taken in the spring.

Seed grown plants are occasionally available at the nursery website at www.hccarnivorousplants.co.uk 


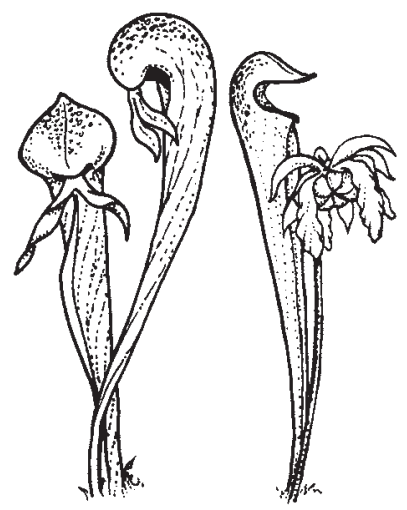

\title{
CARNIVOROUS \\ PLANT \\ NEWSLETTER
}

Journal of the International

Carnivorous Plant Society

www.carnivorousplants.org

Volume 41, Number 3 September 2012

Front Cover: A hapless moth ensnared by a vicious Drosera regia. Photo by Bob Ziemer. Article on page 109.

\section{Back Cover: Damon Collingsworth communing with Sarracenia leucophylla at Splinter Hill Bog Preserve near Rabun, Alabama late in the day. Photo by Damon Collingsworth. Article on page 113.}

Carnivorous Plant N ewsletter is dedicated to spreading knowledge and news related to carnivorous plants. Reader contributions are essential for this mission to be successful. Do not hesitate to contact the editors with information about your plants, conservation projects, field trips, or noteworthy events. A dvertisers should contact the editors. Views expressed in this publication are those of the authors, not the editorial staff.

All correspondence regarding dues, address changes and missing issues should be sent to the Membership Coordinator at the ICPS. D o not send such correspondence to the editors. Checks for subscriptions should be made to the ICPS in US funds. Dues for 2012 are $\$ 35$ for the first year of membership; renewals are $\$ 30$ per year.

\author{
ICPS, Inc. \\ 2530 Patra Drive \\ Richmond, CA 94803, USA \\ icps@ carnivorousplants.org
}

$\begin{array}{ll}\text { President } & \text { Michael Baldwin, michael@ carnivorousplants.org } \\ \text { Vice President } & \text { Marcel van den B roek, marcel@ carnivorousplants.org } \\ \text { Secretary } & \text { Cindy Slezak, cindy@ carnivorousplants.org } \\ \text { Treasurer } & \text { Richard M yers, richard@ carnivorousplants.org } \\ \text { B oard M ember } & \text { B ob Ziemer, bob@ carnivorousplants.org } \\ \text { B oard M ember } & \text { Jan Schlauer, jan@ carnivorousplants.org } \\ \text { B oard M ember } & \text { B rian B arnes, Conservation Director, brian@ carnivorousplants.org } \\ \text { Seed Bank M anager } & \text { John B rittnacher, john@ carnivorousplants.org (see seed bank ad in this issue) }\end{array}$

Editors:

M anaging Editor_Bob Ziemer, bob@carnivorousplants.org

Science Editor Jan Schlauer, jan@ carnivorousplants.org

Science Editor Fernando Rivadavia, fernando@carnivorousplants.org

Editor

Barry Rice, barry@ carnivorousplants.org

Date of effective publication of the J une 2012 issue of Carnivorous Plant N ewsletter: 1 J une 2012.

The ICPS is the International Cultivar Registration A uthority (ICRA) for the names of cultivated carnivorous plants according to the International Code of Nomenclature for Cultivated Plants. Send relevant correspondence to the ICPS, Inc.

Carnivorous Plant N ewsletter is published quarterly in M arch, J une, September, and December by the ICPS, Inc., 2530 Patra Drive, Richmond, CA 94803, USA. Periodicals postage paid at Richmond, CA and additional mailing offices. Postmaster: Send address changes to ICPS, Inc., PM B 322, 1564-A Fitzgerald Drive, Pinole, CA 94564-2229, USA. Printed by A llen Press, Inc., 810 E. 10th Street, L awrence, KS 66044. L ogo and masthead art: Paul M ilauskas.

(c) 2012 Carnivorous Plant N ewsletter. A II rights reserved. ISSN \#0190-9215 